\title{
THE ENZYME ACTIVITIES OF OPINE AND LACTATE DEHYDROGENASES IN THE GILLS, MANTLE, FOOT, AND ADDUCTOR OF THE HARD CLAM MERETRIX LUSORIA
}

An-Chin Lee

Department of Aquatic Biosciences, College of Life Sciences, National Chiayi University, Chiayi City, Taiwan, R.O.C., aclee@mail.ncyu.edu.tw

Kuen-Tsung Lee

Department of Aquatic Biosciences, College of Life Sciences, National Chiayi University, Chiayi City, Taiwan, R.O.C.

Follow this and additional works at: https://jmstt.ntou.edu.tw/journal

Part of the Life Sciences Commons

\section{Recommended Citation}

Lee, An-Chin and Lee, Kuen-Tsung (2011) "THE ENZYME ACTIVITIES OF OPINE AND LACTATE DEHYDROGENASES IN THE GILLS, MANTLE, FOOT, AND ADDUCTOR OF THE HARD CLAM MERETRIX LUSORIA," Journal of Marine Science and Technology. Vol. 19: Iss. 4, Article 4.

DOI: $10.51400 / 2709-6998.2176$

Available at: https://jmstt.ntou.edu.tw/journal/vol19/iss4/4

This Research Article is brought to you for free and open access by Journal of Marine Science and Technology. It has been accepted for inclusion in Journal of Marine Science and Technology by an authorized editor of Journal of Marine Science and Technology. 
THE ENZYME ACTIVITIES OF OPINE AND LACTATE DEHYDROGENASES IN THE GILLS, MANTLE, FOOT, AND ADDUCTOR OF THE HARD CLAM MERETRIX LUSORIA

Acknowledgements

The authors are grateful for financial support from the National Science Council

(NSC97-2313-B-415-003-MY3) and National Chiayi University (NCYU 97T001-05-06-001) of Taiwan, R.O.C. 


\title{
THE ENZYME ACTIVITIES OF OPINE AND LACTATE DEHYDROGENASES IN THE GILLS, MANTLE, FOOT, AND ADDUCTOR OF THE HARD CLAM MERETRIX LUSORIA
}

\author{
An-Chin Lee* and Kuen-Tsung Lee*
}

Key words: hard clam, opine dehydrogenase, tissues, lactate dehydrogenase.

\begin{abstract}
Alanopine dehydrogenase (ADH) and both $\mathrm{ADH}$ and strombine dehydrogenase (SDH) are respectively the major opine dehydrogenases in the gills and mantle of hard clam under normoxia. However, ADH, octopine dehydrogenase (ODH), and SDH are the predominant opine dehydrogenases in the foot and adductor of the hard clam under normoxia. After anoxic exposure, significant increases in the activities of opine dehydrogenases in the gills were observed for ADH as well as SDH and lactate dehydrogenase (LDH). However, the activities of ADH and SDH in the mantle were not responsive to anoxic exposure. Activities of $\mathrm{ADH}, \mathrm{ODH}, \mathrm{SDH}$, and $\mathrm{LDH}$ in the foot were not affected by $3 \mathrm{~h}$ of anoxic exposure, but were significantly increased after $6 \mathrm{~h}$ of anoxic exposure. The major species of opine dehydrogenases in the adductor were the same as those in the foot. The activities of LDH and all opine dehydrogenases except taurine dehydrogenase (TDH) in the adductor were significantly stimulated by anoxic exposure, and their maximum activities were found by $3 \mathrm{~h}$ of anoxic exposure. After anoxic exposure, the rates of increases in the activities of $\mathrm{ADH}, \mathrm{ODH}$, and $\mathrm{SDH}$ in the adductor ranged from 150 to $230 \mathrm{mU} / \mathrm{mg} / \mathrm{h}$ were much higher than those in the gills, mantle, and foot. Therefore, these opine dehydrogenases play an important role in the anaerobic metabolism of the adductor in the hard clam.
\end{abstract}

\section{INTRODUCTION}

Hard clam Meretrix lusoria are benthic marine organisms and naturally inhabit estuaries. However, most hard clam sold in the market is cultured in ponds in the southwestern part of

Paper submitted 08/17/09; revised 01/07/10; accepted 03/23/10. Author for correspondence: An-ChinLee (e-mail:aclee@mail.ncyu.edu.tw).

*Department of Aquatic Biosciences, College of Life Sciences, National Chiayi University, Chiayi City, Taiwan, R.O.C.
Taiwan. The salinity of pond water varies with the site and is maintained at approximately $20 \%$ in the Taishi area of Yunlin County, Taiwan [18]. Normally, the food of juvenile clam is supplied by natural production which may provide insufficient food to meet the needs of clam in the middle and late stages of culture. Therefore, powdered fish meal and fermented organic matter are added to clam ponds to directly feed the clam and enrich natural production. The addition of organic matter to ponds can result in the formation of a reduced layer in the sediments [14]. The reduced layer in the sediment consumes a lot of dissolved oxygen (DO) and results in low levels of DO in the bottom layer of pond water under stagnant conditions [22]. Therefore, hard clam are likely to experience environmental hypoxia in aged ponds.

Physiological functions of organisms are performed by consuming chemical energy, the production of which is achieved by the oxidation of organic matter with consumption of oxygen molecule. There is no problem for land-based animals to extract oxygen molecules from the air. However, marine aquatic organisms, especially those with habitats in sediments, must face the problem of the sources of DO due to the low solubility of oxygen in seawater: $210 \mathrm{ml} \mathrm{O}_{2} / \mathrm{L}$ in air vs. $5.5 \mathrm{ml}$ $\mathrm{O}_{2} / \mathrm{L}$ in seawater at $20^{\circ} \mathrm{C}$ [12]. A decrease in the supply of and a lack of oxygen will result in hypoxia and anoxia, respectively.

Anaerobiosis is divided into two categories, environmental anaerobiosis and functional anaerobiosis; the former is defined as exposure of the entire organism to anoxic conditions, while the latter characterizes the conditions of oxygen consumption in tissues which exceeds the oxygen supply [2].

Anaerobic metabolism in invertebrates is divided into four classes: the aspartate-succinate pathway, the glucose-succinate pathway, the opine pathway, and the lactate pathway (Fig. 1, top panel) $[8,19,20]$. The former two pathways produce energy output at relatively high efficiencies (5 7 ATP molecules per glucose unit) compared to that in the latter two pathways (3 ATP molecules per glucose unit). However, the latter two pathways produce energy at a higher rate than do the former two pathways. The former two pathways were found to exist in hard clam [17]. However, how the latter two path- 

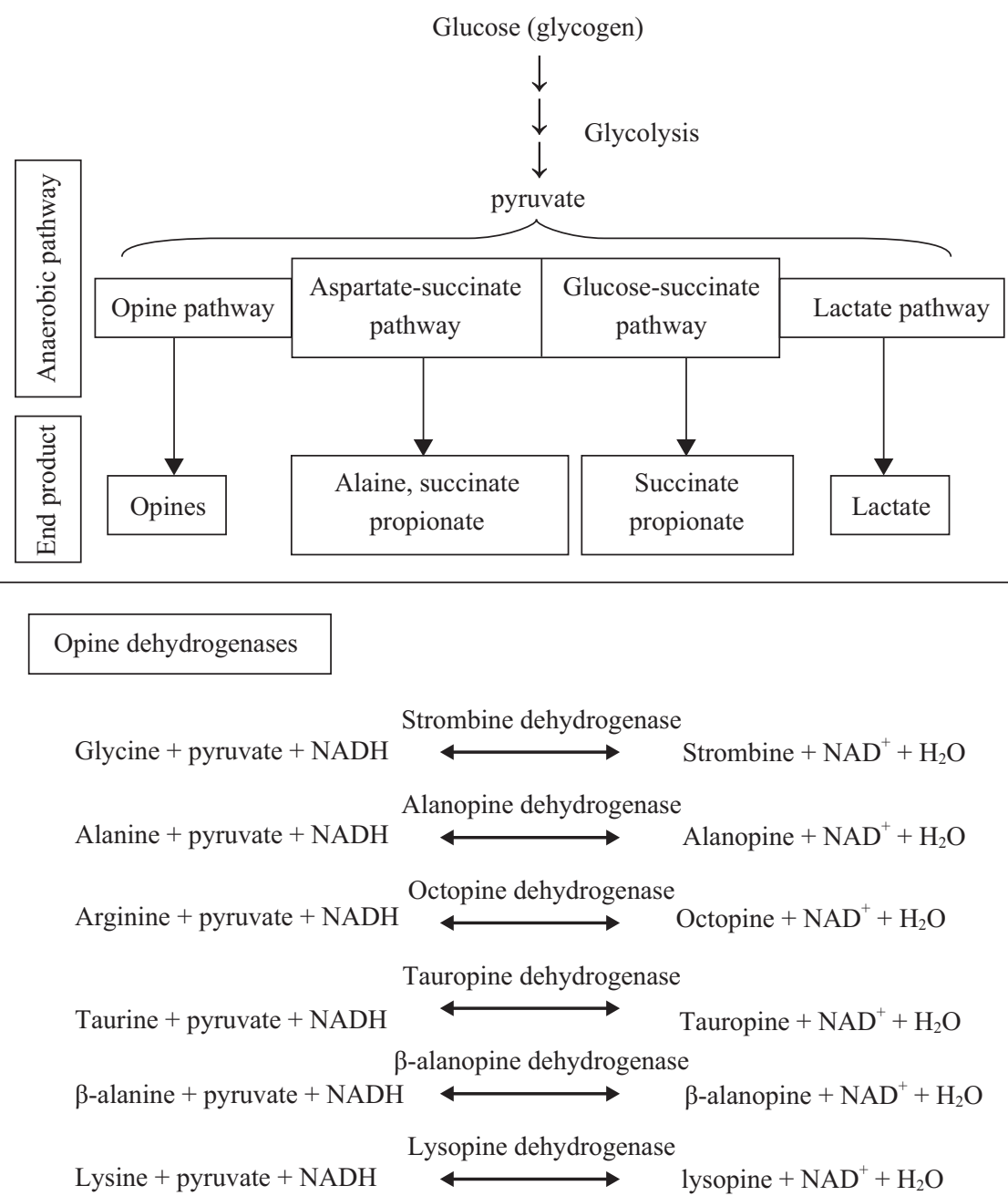

Fig. 1. Four kinds of anaerobic pathways (top panel) and dehydrogenases in opine pathways in mollusks $[4,5,19,20]$.

ways operate in tissues of hard clam under anoxia is still unknown, although the activities of opine dehydrogenases and lactate dehydrogenase (LDH) were found in the foot and adductor of the hard clam [25].

Opine dehydrogenases are a family of enzymes which can catalyze one mole of amino acids and pyruvate to form one mole of opine as well as oxidize one mole of NADH (Fig. 1, bottom panel). The function of opine dehydrogenase is similar to that of LDH. These dehydrogenases can oxidize NADH produced by glycolysis in the cytosol and promote glycolysis to yield more ATP for physiological functioning under anoxia. The first opine dehydrogenase discovered was alanopine dehydrogenase $(\mathrm{ADH})$ which was found in the adductor of the Pacific oyster [9]. Thereafter, several kinds of opine dehydrogenases were found in many kinds of organisms, such as strombine dehydrogenase (SDH) in Mytilus edulis [7], octopine dehydrogenase (ODH) in Cerebratulus lacteus [13], $\beta$-alanopine dehydrogenase (BADH) in Scapharca broughtonii [24], and tauropine dehydrogenase (TDH) in Arabella iricolor [16].
Because hard clam are often exposed to hypoxia in aged culture ponds, understanding their anaerobic metabolism is very important to be able to evaluate their resistance to anoxia/ hypoxia. The aim of this study was to determine the activities of opine dehydrogenases (ADH, BADH, lysopine dehydrogenase (LYDH), ODH, SDH, and TADH) and LDH in the gills, mantle, foot, and adductor of hard clam and to discuss the importance of these enzymes in their physiological function.

\section{MATERIAL AND METHODS}

\section{Animals}

Hard clam (16.2 $\pm 0.5 \mathrm{~g}$ ) was purchased from clam farms in the Taishi area (Yunlin County, southwestern Taiwan) and starved for 2 days in 2000-L tanks containing $1300 \mathrm{~L}$ of $20 \%$ artificial seawater (ASW) prepared by dissolving 1:50 (w/v) of synthetic sea salts (Meersaltz ${ }^{\circledR}$, Heinsberg, Germany) in tap water. No food was provided during the starvation period. The dissolved oxygen (DO) in the seawater was maintained at $\geq 7 \mathrm{mg} / 1$. 


\section{Normoxic and Anoxic Exposure of Hard Clam}

After starvation, six clams were sampled as a replicate, and there were six replicates at $0 \mathrm{~h}$ (under normoxia). A plastic reservoir with 12 L of $20 \%$ ASW and 36 glass jars were bubbled with $\mathrm{N}_{2}$ for $2 \mathrm{~h}$. After bubbling, 108 clams were placed in the plastic reservoir with $\mathrm{N}_{2}$ gas blowing over them. Six clams were sealed in a glass jar inside the plastic reservoir. Eighteen glass jars were placed in a water bath at $25^{\circ} \mathrm{C}$. Six glass jars were respectively sampled at 3,6 , and $24 \mathrm{~h}$ (anoxic exposure).

\section{Collection of Specimens and Preparation of Crude Extracts from Clam Tissues}

The gills, mantle, foot, and adductor of six clams in each glass jar were respectively dissected and stored in liquid nitrogen until use. The frozen tissues of six clams from a jar were homogenized in a ratio of 1:10 (w/v) with homogenization buffer containing $50 \mathrm{mM}$ Tris, $2 \mathrm{mM}$ EDTA, and 1 $\mathrm{mM}$ DTT at $\mathrm{pH} 7.5$ [7]. The homogenate was centrifuged at $48,000 \mathrm{~g}$ for $30 \mathrm{~min}$ at $4^{\circ} \mathrm{C}$. The supernatant was collected and passed through a Sephadex G-25 column to remove the salt and small molecules.

\section{Determination of the Activities of Opine Dehydrogenases and Protein}

\section{1) Activities of Opine Dehydrogenases}

The assay for the activity of opine dehydrogenases was based on the method described by de Zwaan and Zurburg [7]. The assay buffer for the activities of opine dehydrogenases was $100 \mathrm{mM}$ triethanolamine- $\mathrm{HCl}, 1 \mathrm{mM} \mathrm{KCN}, 5 \mathrm{mM}$ pyruvate, $0.24 \mathrm{mM} \mathrm{NADH}$, and specific amino acids at $\mathrm{pH} 7.5$. The specific amino acids for ADH, ODH, SDH, TDH, BADH, and LYDH were $100 \mathrm{mM}$ alanine, $5 \mathrm{mM}$ arginine, $100 \mathrm{mM}$ glycine, $80 \mathrm{mM}$ taurine, $100 \mathrm{mM} \beta$-alanine, and $100 \mathrm{mM}$ lysine, respectively [1]. The activity of LDH was assayed as described above except in the absence of a specific amino acid. The activities of LDH and opine dehydrogenases were monitored by changes in the absorbance at $340 \mathrm{~nm}$ at $25^{\circ} \mathrm{C}$. One unit of activity was defined as the amount of enzymes which consumed one micromole of NADH per minute.

\section{2) Protein}

Samples were precipitated using 10\% trichloroacetic acid to remove DTT which interferes in the protein assay. The resulting precipitate was assayed by a BCA Protein Assay Kit.

\section{Analysis of Data}

All data were statistically analyzed by analysis of variance (ANOVA) [26] using SigmaStat statistical software from SPSS. Duncan's test for pairwise comparisons was used at the $5 \%$ significance level.

\section{RESULTS}

$\mathrm{ADH}$ is the major opine dehydrogenase in the gills of hard

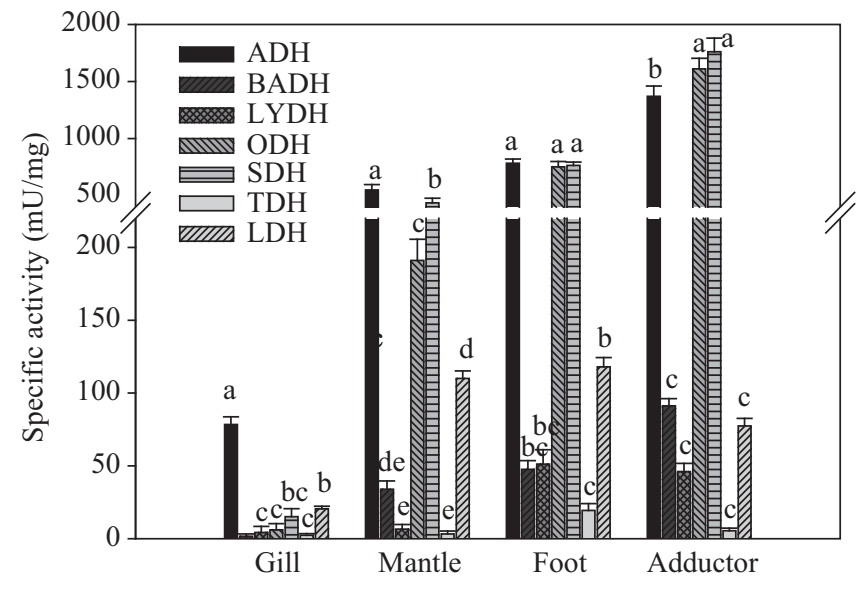

Fig. 2. Activities of ADH, BADH, LYDH, ODH, SDH, TDH, and LDH in the gill, mantle, foot and adductor of hard clam under normoxia. Names of dehydrogenases were abbreviated as those in Fig. 1. Data are given as the mean with the standard error. Significant $(<0.05)$ differences in the tissues are denotes by different letters.

clam under normoxia. Its specific activity was $78.4 \mathrm{mU} / \mathrm{mg}$ protein. The activity of the other opine dehydrogenases in the gill was $\leq 15.1 \mathrm{mU} / \mathrm{mg}$ protein and was much lower than that of $\mathrm{ADH}$ (Fig. 2). $\mathrm{ADH}$ and $\mathrm{SDH}$ are the major opine dehydrogenases in the mantle of hard clam kept in aerated seawater, followed by the activities of $\mathrm{ODH}$ and $\mathrm{LDH}$. However, the activities of BADH, LYDH, and TDH among mantle opine dehydrogenases were minor. It is notable that $\mathrm{ADH}, \mathrm{ODH}$, and SDH predominate the opine dehydrogenases in the foot and adductor of hard clam under normoxia. The activities of $\mathrm{ODH}$ and SDH were significantly higher than that of $\mathrm{ADH}$ in the adductor, while the activity of the latter was significantly higher than those of the former in the gills and mantle (Fig. 2).

In gills of the hard clam subjected to anoxic exposure, significant increases in the activities of opine dehydrogenases were observed in ADH as well as in SDH and LDH. Their activities were the highest at $3 \mathrm{~h}$ of anoxic exposure: $284 \mathrm{mU} / \mathrm{mg}$ protein for $\mathrm{ADH}, 78.8 \mathrm{mU} / \mathrm{mg}$ protein for $\mathrm{SDH}$, and 94.4 $\mathrm{mU} / \mathrm{mg}$ protein for LDH. Their activities at $6 \mathrm{~h}$ and $24 \mathrm{~h}$ of anoxic exposure were significantly lower than those at $3 \mathrm{~h}$ of anoxic exposure, but they were still higher than those under normoxia (Fig. 3). No significant changes in the activities of $\mathrm{BADH}, \mathrm{LYDH}, \mathrm{ODH}$, and TDH in the gill were observed after anoxic exposure.

Although the activities of $\mathrm{ADH}$ and $\mathrm{SDH}$, at 549 and 436 $\mathrm{mU} / \mathrm{mg}$ protein, in the mantle were much higher than those, at 78.4 and $15.1 \mathrm{mU} / \mathrm{mg}$ protein, respectively, in the gills (Fig. 2), their activities were not responsive to anoxic exposure (Fig. 4). In addition, there were no significant changes in the activities of the other opine dehydrogenases in the mantle of hard clam exposed to anoxia (Fig. 4). The activity of LDH in the mantle was not affected by $6 \mathrm{~h}$ of anoxia exposure, while $24 \mathrm{~h}$ of anoxia exposure stimulated a significant change in its activity.

$\mathrm{ADH}, \mathrm{ODH}$, and $\mathrm{SDH}$ predominated in the foot not only 


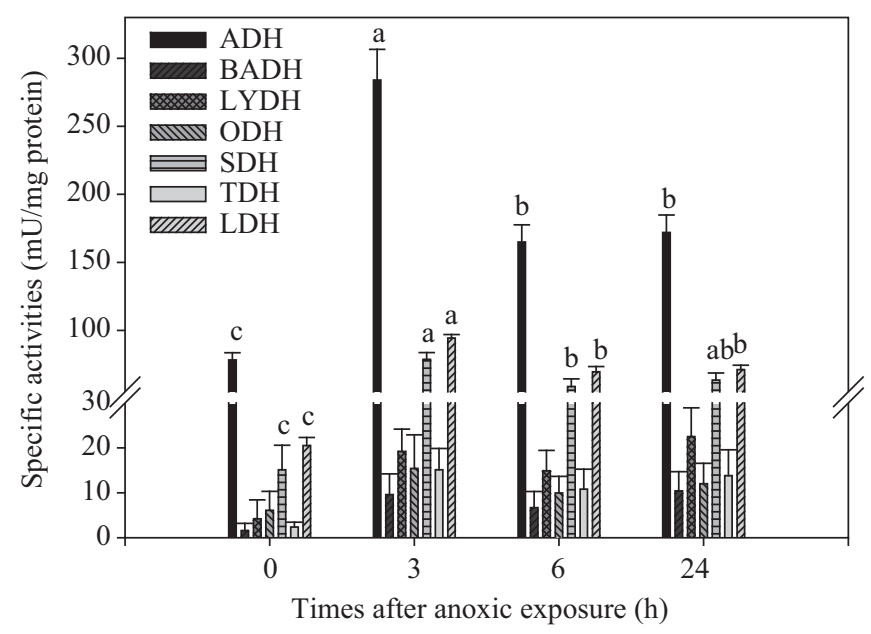

Fig. 3. Activities of ADH, BADH, LYDH, ODH, SDH, TDH, and LDH in the gill of hard clam after anoxic exposure. Names of dehydrogenases were abbreviated as those in Fig. 1. Data are given as the mean with the standard error. Significant $(<0.05)$ differences in a specific dehydrogenase are denotes by different letters.

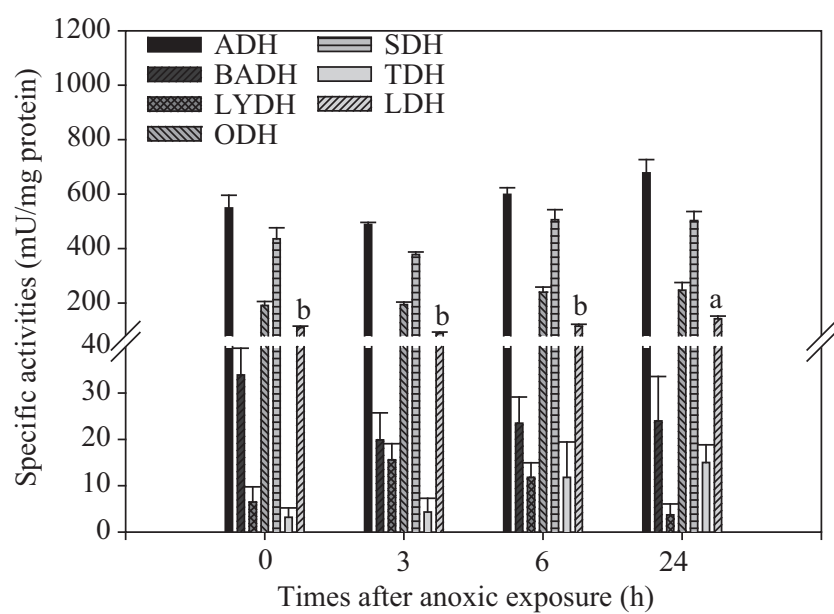

Fig. 4. Activities of ADH, BADH, LYDH, ODH, SDH, TDH, and LDH in the mantle of hard clam after anoxic exposure. Names of dehydrogenases were abbreviated as those in Fig. 1. Data are given as the mean with the standard error. Significant differences $(<0.05)$ in a specific dehydrogenase are denotes by different letters.

under normoxia but also after anoxic exposure (Fig. 5). Their activities were not affected by $3 \mathrm{~h}$ of anoxic exposure, significantly increased after $6 \mathrm{~h}$ of anoxic exposure, and reached a maximum after $24 \mathrm{~h}$ of anoxic exposure. The activity of LDH in the foot did not significantly increase until by $6 \mathrm{~h}$ of anoxic exposure. After anoxic exposure, no significant changes in the activities of BADH, LYDH, and TDH in the foot were observed.

The major species of opine dehydrogenases, $\mathrm{ADH}, \mathrm{ODH}$, and $\mathrm{SDH}$, in the adductor were the same as those in the foot (Fig. 6). The activities of LDH and all opine dehydrogenases except TDH in the adductor were significantly stimulated by

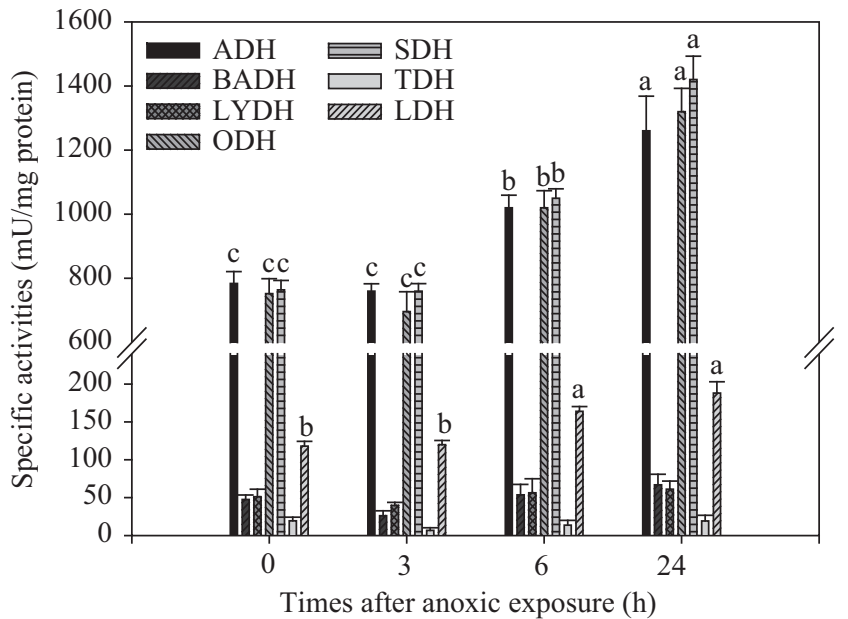

Fig. 5. Activities of ADH, BADH, LYDH, ODH, SDH, TDH, and LDH in the foot of hard clam after anoxic exposure. Names of dehydrogenases were abbreviated as those in Fig. 1. Data are given as the mean with the standard error. Significant differences $(<0.05)$ in a specific dehydrogenase are denotes by different letters.

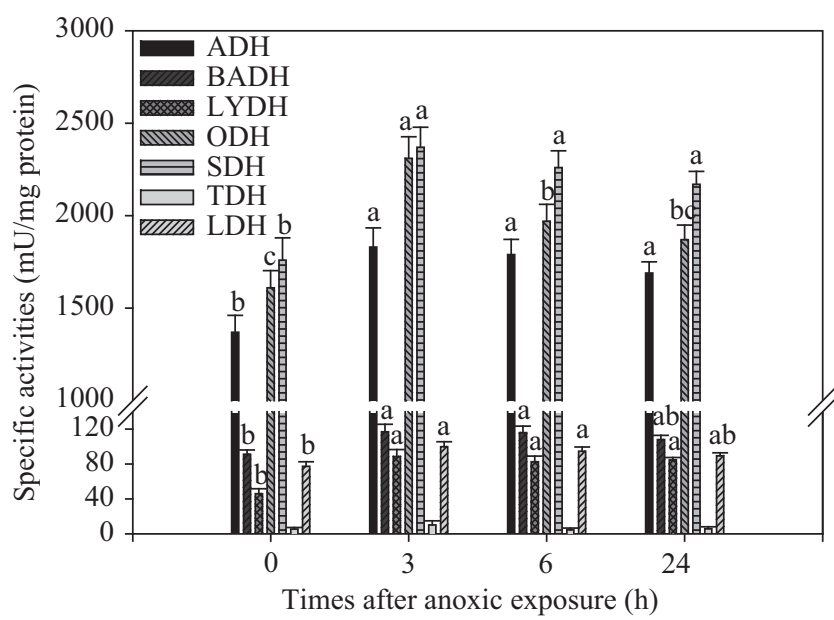

Fig. 6. Activities of ADH, BADH, LYDH, ODH, SDH, TDH, and LDH in the adductor of hard clam after anoxic exposure. Names of dehydrogenases were abbreviated as those in Fig. 1. Data are given as the mean with the standard error. Significant differences $(<0.05)$ in a specific dehydrogenase are denotes by different letters.

anoxic exposure, and their maximum activities were found at $3 \mathrm{~h}$ of anoxic exposure. Although the activities of BADH, LYDH, and LDH responded to anoxic exposure, their total activities were approximately $5 \%$ of one of the major opine dehydrogenases. Therefore, they have little importance in anaerobic metabolism of the adductor.

Maximum activities of lactate and opine dehydrogenases in the gills, mantle, foot, and adductor were seen at $3,24,24$, and $3 \mathrm{~h}$ of anoxic exposure, respectively. After anoxic exposure, the rates of increases in the activities of $\mathrm{ADH}, \mathrm{ODH}$, and $\mathrm{SDH}$, 150 $230 \mathrm{mU} / \mathrm{mg}$ protein/ $\mathrm{h}$, in the adductor were much higher than those in the gills, mantle, and foot (Fig. 7). The species of 


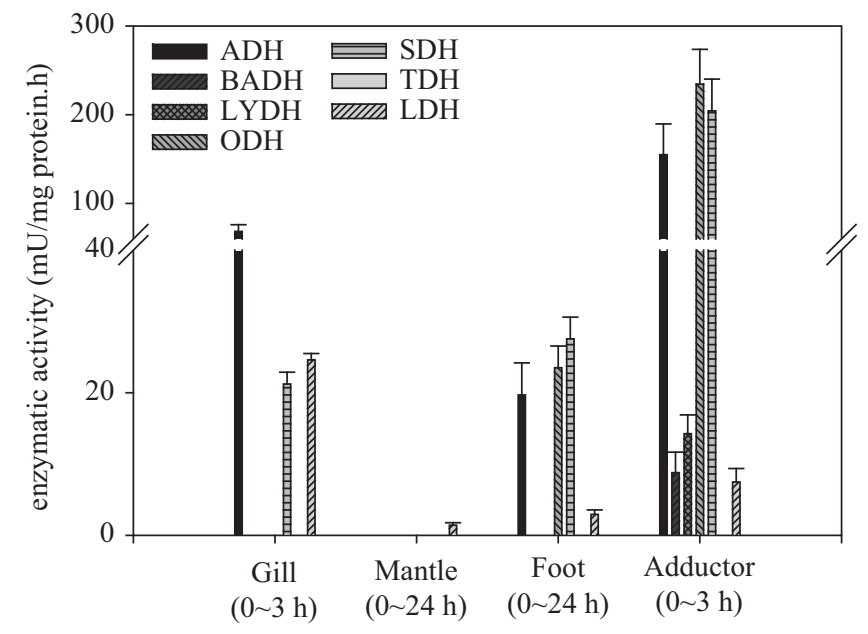

Fig. 7. Enzymatic activities of ADH, BADH, LYDH, ODH, SDH, TDH, and LDH in the tissues of hard clam after anoxic exposure. Names of dehydrogenases were abbreviated as those in Fig. 1. Data are given as the mean with the standard error. The number in parenthesis indicates anoxic exposure period for calculating enzymatic activities.

opine dehydrogenases with a higher increase rate in the gill was $\mathrm{ADH}$, while those in the foot and adductor were $\mathrm{ADH}$, $\mathrm{ODH}$, and SDH. It was interesting that the rate of increase in the activity of SDH in the gill was comparable to that in the activity of LDH.

\section{DISCUSSION}

Under environmental hypoxia/anoxia, organisms cannot take up sufficient oxygen molecules for physiological function. This results in a decrease in the $p \mathrm{O}_{2}$ of the hemolymph of bivalves. After Mytilus edulis was exposed to air, the $p \mathrm{O}_{2}$ of hemolymph sharply declined within the first few hours from 80 to $40 \mathrm{mmHg}$ and was maintained at this level for $24 \mathrm{~h}$ of anoxic exposure [6]. A similar observation was also found in the hard clam. The hemolymph $p \mathrm{O}_{2}$ of hard clam decreased from $23.8 \mathrm{mmHg}$ initially to $18.3 \mathrm{mmHg}$ after $1 \mathrm{~min}$ of exposure at $15^{\circ} \mathrm{C}$. Subsequently, it significantly dropped to 5.9 $\mathrm{mmHg}$ after $2 \mathrm{~min}$ of exposure, and thereafter, low-level values were maintained until $3 \mathrm{~min}$ of exposure [15]. Huang et al. [15] also determined the effect of $\mathrm{Mg}^{+2}$-free artificial seawater, $\mathrm{K}^{+}$, and $\mathrm{KCN}$ on the hemolymph $p \mathrm{O}_{2}$ of hard clam. A constant value of their hemolymph $p \mathrm{O}_{2}$ of $>10 \mathrm{mmHg}$ was observed for the entire exposure period of $48 \mathrm{~h}$. M. edulis and M. lusoria have no hemoglobin, while a minor amount of hemocyanins is present in the hemolymph of hard clam $[12,15]$. Possible explanations for the reason why hemolymph $p \mathrm{O}_{2}$ does not drop to zero may be due to air gaping, impacting oxygen uptake by tissues, or the onset of anaerobiosis.

In mollusks, both opine dehydrogenases and LDH are well known as terminal enzymes for regulating the cytosolic redox balance in glycolysis under anoxia [4]. The catalytic mechanisms of both dehydrogenases are simple, and their favorite reaction direction totally depends on the equilibrium constant. Their reaction rates are rapid, but the efficiency of energy production is relatively low. The function of vigorous muscular activity, characterized by sudden energy demands, is performed by the organs of foot and adductor of mollusks. High activities of ADH, ODH, and SDH were found in the foot and adductor of hard clam and presumably account for the instant energy supply in functional anaerobiosis. This observation is consistent with results of high activities of $\mathrm{ADH}, \mathrm{ODH}$, and $\mathrm{SDH}$ in the foot and adductor of the bivalves Meretrix lusoria, Scapharca inequivalvis, and M. edulis [7, 20, 25]. However, the gills are responsible for respiratory function and, unlike the foot and adductor, do not have "bursts" of contractions. The gills having low activities of $\mathrm{ADH}, \mathrm{ODH}$, and SDH could also explain the role of these dehydrogenases in functional anaerobiosis. Similarly, the gills having low activities of these dehydrogenases were also observed in the sea mussel $M$. edulis and oyster Gryphea angulata, while no activity of $\mathrm{ODH}$ was found in gills of G. angulata [7].

Opine dehydrogenases require pyruvate and amino acids as their substrates. Therefore, free amino acids in tissues are re quired for the reactions catalyzed by these dehydrogenases. In kinetics studies, high concentrations of alanine and glycine are respectively required for appreciable enzyme activities of $\mathrm{ADH}$ and $\mathrm{SDH}$, and the apparent $\mathrm{Km}$ values for alanine and glycine are on the order of 170 240 mM [11]. The role of free amino acids in osmoregulation of marine invertebrates is well established [27]. Due to the osmotic balance, the concentrations of free amino acids in the tissues of marine invertebrates are much higher than those in their freshwater counterparts. This is why no opine dehydrogenases were found in freshwater bivalves [21]. Chiou et al. [3] determined the concentrations of 22 species of amino acids in the edible meat of hard clam. Among them, amino acids with concentrations of $>0.5 \mathrm{mg} / \mathrm{L} \cdot \mathrm{g}$ wet weight were taurine $(6.5 \mathrm{mg} / \mathrm{L} \cdot \mathrm{g}$ wet weight $)$, glutamic acid $(1.5 \mathrm{mg} / \mathrm{L} \cdot \mathrm{g}$ wet weight $)$, glycine $(0.6 \mathrm{mg} / \mathrm{L} \cdot \mathrm{g}$ wet weight $)$, alanine $(2 \mathrm{mg} / \mathrm{L} \cdot \mathrm{g}$ wet weight $)$, and arginine $(0.9 \mathrm{mg} / \mathrm{L} \cdot \mathrm{g}$ wet weight). The low concentration of substrates explains the low activities of BADH and LYDH in tissues of the hard clam. It is interesting that the concentrations of taurine and glutamate in tissues of the hard clam are high, but their respective opine dehydrogenase activities are low and undetectable (data not shown). This phenomenon indicates that the sole role of glutamate and taurine is in osmoregulation. Concentrations of arginine in the gills, mantle, foot, and adductor were $0.5,0.7$, 0.5 , and $1 \mathrm{mg} / \mathrm{g}$ wet weight, while the activities of ODH in these organs were $6.08,191,752$, and $1610 \mathrm{mU} / \mathrm{mg}$ protein, respectively [23]. This indicates that the activity of $\mathrm{ODH}$ in the gills is tissue-specific rather than being related to the concentration of arginine. However, the activity of ADH depends on the concentration of alanine in tissues since concentrations of alanine in the gills, mantle, foot, and adductor were 1.5, 4, 6.1 , and $7.03 \mathrm{mg} / \mathrm{g}$ wet weight, respectively [23]. Concentrations of glycine in the adductor and gills were respectively the highest and lowest and were comparable to the trend of the 
activity of SDH in both organs.

Although the physiological role of opine dehydrogenases is analogous to that of $\mathrm{LDH}$, anaerobic opine pathways are widely distributed in marine invertebrates instead of the wellknown lactate pathway which is predominant in vertebrates [25]. In vertebrates, $\mathrm{LDH}$ is used to maintain the cytosolic redox balance in anaerobiosis, while opine dehydrogenases are used to regulate this redox balance in some marine invertebrates. On the other hand, the opine pathway and lactate pathway predominate in less-mobile animals with poorly developed organs and in much more-mobile animals with welldeveloped organs, respectively [25]. Therefore, the lactate pathway selected by vertebrates might have been due to the development of circulatory systems and other means of removing acidic lactate end-products. The reason that the lactate pathway occurs in phylogenically higher animals may partly be that the energy production rate of the lactate pathway is greater because its operation is only limited by the size of the carbohydrate pool. The reason that the opine pathway is widely distributed in phylogenically lower animal can be explained by a study using a computer simulation in which the cytosolic redox ratio $\left(\mathrm{NADH} / \mathrm{NAD}^{+}\right)$with octopine as the end product was small compared to that with lactate as the end product [10]. The activities of LDH in the foot and adductor of hard clam were respectively $5 \%$ and $1.6 \%$ of the activity of all opine dehydrogenases in our study. This is consistent with the finding of Sato et al. [25]. Therefore, the role of opine dehydrogenases is more important than that of LDH in anaerobic metabolism of bivalves.

\section{ACKNOWLEDGMENTS}

The authors are grateful for financial support from the National Science Council (NSC97-2313-B-415-003-MY3) and National Chiayi University (NCYU 97T001-05-06-001) of Taiwan, R.O.C.

\section{REFERENCES}

1. Baldwin, J., Elias, J. P., Wells, R. M. G., and Donovan, D. A., “Energy metabolism in the tropical abalone, Haliotis asinina Linné: comparisons with temperate abalone species," Journal of Experimental Marine Biology and Ecology, Vol. 342, pp. 213-225 (2007).

2. Carroll, J. L. and Wells, R. M. G., "Strategies of anaerobiosis in New Zealand infaunal bivalves: adaptations to environmental and functional hypoxia," New Zealand Journal of Marine and Freshwater Research, Vol. 29, pp. 137-146 (1995).

3. Chiou, T. K., Lin, J. F., and Shiau, C. Y., "Changes in extractive components and glycogen in the edible meat of hard clam Meretrix lusoria during storage at different temperatures," Fisheries Science, Vol. 64, pp. 115-120 (1998).

4. Dando, P. R., Storey, K. B., Hochachka, P. W., and Storey, J. M., "Multiple dehydrogenases in marine molluscs: electrophoretic analysis of alanopine dehydrogenase, strombine dehydrogenase, octopine dehydrogenase and lactate dehydrogenase," Marine Biology Letters, Vol. 2, pp. 249-257 (1981).

5. De Zwaan, A., The Mollusca, Vol. I, Academic Press, New York, pp. 137175 (1983).
6. De Zwaan, A., Bont, A. M. T., Zurburg, W., Bayne, B. L., and Livingstone, D. R., "On the role of strombine formation in the energy metabolism of adductor muscle of a sessile bivalve," Journal of Comparative Physiology, Vol. 149, pp. 557-563 (1983).

7. De Zwaan, A. and Zurburg, W., "The formation of strombine in the adductor muscle of the sea mussel Mytilus edulis L.," Marine Biology Letters, Vol. 2, pp. 179-192 (1981).

8. Eberlee, J. C., Storey, J. M., and Storey, K. B., "Anaerobiosis, recovery from anoxia, and the role of strombine and alanine in the oyster Crassostrea virginica," Canadian Journal of Zoology, Vol. 61, pp. 2682-2687 (1983).

9. Fields, J. H. A., "A dehydrogenase requiring alanine and pyruvate as substrates from oyster adductor muscle," Federation Proceedings, Vol. 35, pp. 1687 (1976).

10. Fields, J. H. A. and Quinn, J. F., "Some theoretical considerations on cytosolic redox balance during anaerobiosis in marine invertebrates," Journal Theoretical Biology, Vol. 88, pp. 35-45 (1981).

11. Fields, J. H. A. and Storey, K. B., "Tissue-specific alanopine dehydrogenase from the gill and strombine dehydrogenase from the foot muscle of the cherrystone clam Mercenaria mercenaria (Linné.)," Journal of Experimental Marine Biology and Ecology, Vol. 105, pp. 175-185 (1987).

12. Gäde, G., "Energy metabolism of arthropods and mollusks during environmental and functional anaerobiosis," Journal of Experimental Zoology, Vol. 228, pp. 415-429 (1983).

13. Gäde, G. and Carlsson, K. H., "Purification and characterisation of octopine dehydrogenase from the marine nemertean Cerebratulus lacteus (Anopla: Heteronemerta): Comparison with scallop octopine dehydrogenase," Marine Biology, Vol. 79, pp. 39-45 (1984).

14. Hon, Y. D., "The investigation and experiment of the bottom soil of the hard clams Meretrix lusoria ponds," Bulletin Taiwan Fisheries Research Institute, Vol. 45, pp. 45-56 (1988).

15. Huang, S. L., Lee, M. C., Chen, S. M., and Lee, A. C., "The acid-base balance of the hemolymph of the hard clam (Meretrix lusoria) is affected by aerial exposure and cellular hypoxia-inducing factors," Journal of the Fisheries Society of Taiwan, Vol. 34, pp. 177-185 (2007).

16. Kanno, N., Sato, M., Nagahisa, E., and Sato, Y., “Tauropine dehydrogenase from the sandworm Arabella iricolor (Polychaeta: Errantia): purification and characterization," Comparative Biochemistry and Physiology, Vol. 114B, pp. 409-416 (1996).

17. Lee, A. C., Lee, M. C., Lee, Y. H., and Lee, Y. C., "Candidates for a hypoxia- stress indicator in the hard clam, Meretrix lusoria," Aquaculture, Vol. 278, pp. 150-155 (2008).

18. Lee, A. C., Lin, Y. H., Lin, C. R., Lee, M. C., and Chen, Y. P., "Effects of components in sea water on the digging behavior of the hard clam (Meretrix lusoria)," Aquaculture, Vol. 272, pp. 636-643 (2007).

19. Livingstone, D. R., "Invertebrate and vertebrate pathways of anaerobic metabolism: evolutionary considerations," Journal Geological Society, Vol. 140, pp. 27-37 (1983).

20. Livingstone, D. R., de Zwaan, A., Leopold, M., and Marteijn, E., "Studies on the phylogenetic distribution of pyruvate oxidoreductases," Biochemical Systematics and Ecology, Vol. 11, No. 4, pp. 415-425 (1983).

21. Livingstone, D. R., Stickle, W. B., Kapper, M. A., Wang, S., and Zurburg, W., "Further studies on the phylogenetic distribution of pyruvate oxidoreductase activities," Comparative Biochemistry and Physiology, Vol. 97B, pp. 661-666 (1990).

22. Meijer, L. E. and Avnimelech, Y., "On the use of micro-electrodes in fish pond sediments," Aquacultural Engineering, Vol. 21, pp. 71-83 (1990).

23. Okuma, E., Watanabe, K., and Abe, H., "Distribution of free D-amino acids in bivalve mollusks and the effect of physiological conditions on the levels of D- and L- alanine in the tissues of the hard clam, Meretrix lusoria," Fisheries Science, Vol. 64, No. 4, pp. 606-611 (1998).

24. Sato, M., Takahara, M., Kanno, N., Sato, Y., and Ellington, W. R., "Isolation of a new opine, $\beta$-alanopine, from the extracts of the muscle of the marine bivalve mollusc, Scapharca broughtonii," Comparative Biochemistry and Physiology, Vol. 88B, pp. 803-806 (1987).

25. Sato, M., Takeuchi, M., Kanno, N., Nagahisa, E., and Sato, Y., "Distri- 
bution of opine dehydrogenases and lactate dehydrogenase activities in marine animals," Comparative Biochemistry and Physiology, Vol. 106B, pp. 955-960 (1993).

26. Steel, R. G. D. and Torrie, J. H., Principles and Procedures of Statistics,
McGraw-Hill, New York (1960).

27. Zurburg, W. and de Zwaan, A., "The role of amino acids in anaerobiosis and osmoregulation in Bivalves," Journal of Experimental Zoology, Vol. 215, pp. 315-325 (1981). 